\title{
A comparison of in situ vs. ex situ filtration methods on the assessment of dissolved and particulate metals at hydrothermal vents
}

\author{
Cotte Laura ${ }^{1,2,3,{ }^{*}}$, Waeles Mathieu ${ }^{1,2}$, Pernet-Coudrier Benoît ${ }^{1,2}$, Sarradin Pierre-Marie ${ }^{3}$, \\ Cathalot Cécile ${ }^{4}$, Riso Ricardo D. ${ }^{1,2}$
}

${ }^{1}$ Univ Europeenne Bretagne, Brest, France.

${ }^{2}$ Univ Bretagne Occidentale, Grp Chim Marine, CNRS, IUEM,LEMAR,UMR 6539, F-29280 Plouzane, France.

${ }^{3}$ IFREMER Ctr Brest, Lab Environm Profond LEP DEEP REM, F-29280 Plouzane, France.

${ }^{4}$ IFREMER Ctr Brest, Lab Geochim \& Metallogenie LGM GM REM, F-29280 Plouzane, France.

* Corresponding author : Laura Cotte, email address : laura.cotte@univ-brest.fr

\begin{abstract}
:
The objective of this study was to assess the impact of the filtration method (in situ vs. ex situ) on the dissolved/particulate partitioning of 12 elements in hydrothermal samples collected from the Lucky Strike vent field (Mid-Atlantic Ridge; MAR). To do so, dissolved $(<0.45 \mu \mathrm{m})$ and particulate $\mathrm{Mg}, \mathrm{Li}, \mathrm{Mn}$, $\mathrm{U}, \mathrm{V}, \mathrm{As}, \mathrm{Ba}, \mathrm{Fe}, \mathrm{Zn}, \mathrm{Cd}, \mathrm{Pb}$ and $\mathrm{Cu}$ were measured using different techniques (HR-ICP-MS, ICP-AES and CCSA). Using in situ filtration as a baseline, we showed that ex situ filtration (on-board and on shore after freezing) resulted in an underestimation of the dissolved pool, which was counterbalanced by an overestimation of the particulate pool for almost all the elements studied. We also showed that on-board filtration was acceptable for the assessment of dissolved and particulate $\mathrm{Mn}, \mathrm{Mg}$, Li and $\mathrm{U}$ for which the measurement bias for the dissolved fraction did not exceed $3 \%$. However, in situ filtration appeared necessary for the accurate assessment of the dissolved and particulate concentrations of $\mathrm{V}$, As, $\mathrm{Fe}, \mathrm{Zn}, \mathrm{Ba}, \mathrm{Cd}, \mathrm{Pb}$ and $\mathrm{Cu}$. In the case of $\mathrm{Fe}$, on-board filtration underestimated the dissolved pool by up to $96 \%$. Laboratory filtration (after freezing) resulted in a large bias in the dissolved and particulate concentrations, unambiguously discounting this filtration method for deep-sea chemical speciation studies. We discuss our results in light of the precipitation processes that can potentially affect the accuracy of ex situ filtration methods.
\end{abstract}




\section{Graphical abstract}

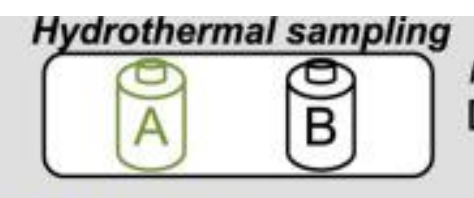

In-Situ filtered Unfiltered

(Reference)

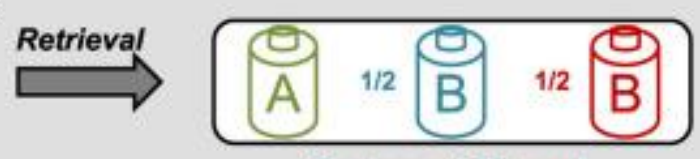

\section{On board filtered}

(Reference)

\section{ICP-MS \& ICP-AES}

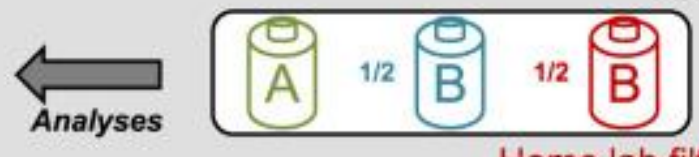

Home lab filtered

\section{Highlights}

- We compared three different filtration methods on hydrothermal samples. Dissolved metals are underestimated after post-sampling filtrations. On board filtration is suitable for dissolved and particulate $\mathrm{Mn}, \mathrm{Li}, \mathrm{Mg}$ and $\mathrm{U}$. In situ filtration is essential for $\mathrm{V}, \mathrm{As}, \mathrm{Ba}, \mathrm{Fe}, \mathrm{Zn}, \mathrm{Cd}, \mathrm{Pb}$ and $\mathrm{Cu}$. Precipitation of sulfides and/or Fe-oxyhydroxide can explain this underestimation.

Keywords : Metal, Hydrothermal vent, Dissolved, Particulate, Filtration method 
 \\ 1. Introduction}

Assessing the behavior of trace metals is essential for understanding the link between metal composition and the distribution of deep-sea hydrothermal fauna (Sarradin et al. 2008). Some studies have suggested that local biological assemblages are partly controlled by geochemical conditions, including trace metal speciation along the hydrothermal fluid-seawater mixing gradient (Shank et al. 1998; Luther et al. 2001). The hydrothermal mixing gradient can be schematically split up into three areas: the "anoxic zone" (hot fluid), the "mixing zone", characterized by steep chemical gradients (Johnson et al. 1986; Le Bris et al. 2003) when hot, reduced hydrothermal fluid mixes with cold, oxidized seawater, and the "oxic zone" (cold seawater).

Substantial efforts have been devoted to understanding the physico-chemical behavior of metal in these different areas. Previous studies assessing the dissolved metal input from hydrothermal vents have focused on the non-buoyant plume (Bennett et al. 2008), whereas others have evaluated total dissolvable metal levels in endmember hydrothermal fluids (Charlou et al. 2000). Still other studies have considered the chemical composition of particles (Feely et al. 1994; German et al. 2002) and their kinetics of formation (Rudnicki and Elderfield 1993), focusing on the buoyant and/or the non-buoyant plume of high-temperature black smokers. In the mixing zone, secondary reactions of complexation between dissolved metal and organic metal-binding ligands may influence the chemical speciation of metal, and compete with sulfide precipitation (Sander et al. 2007; Toner et al. 2009; Yücel et al. 2011; Hawkes et al. 2013), potentially increasing the dissolved metal flux in the deep ocean (Sander and Koschinsky 2011).

Metal behavior in the mixing zone is still poorly documented despite its significant impact on metal speciation, and data are still lacking in this specific environment (Von Damm et al. 1985; Field and Sherrell 2000; Kádár et al. 2005; Sander et al. 2007; Sarradin et al. 2008; 
Sarradin et al. 2009). Data from the mixing zone show substantial variability, likely exacerbated by inappropriate sampling methods and an insufficient number of samples for this study area (Kádár et al. 2005). Despite remarkable improvement in the technical means for deep-sea exploration and research over the past 20 years, most scientists perform on-board filtration (typically $0.45 \mu \mathrm{m}$ ) after retrieval of deep-sea samples (Von Damm et al. 1985; Sander et al. 2007; Bennett et al. 2008; Sarradin et al. 2009; Yücel et al. 2011), despite being aware of the potential alteration of the chemical speciation due to dramatic changes in temperature and pressure and/or chemical equilibrium.

Commonly used in surface-water sampling (Gimpel et al. 2003), in situ filtration can reduce this chemical alteration, potentially caused by precipitation and/or adsorption of some dissolved elements. Obviously, direct in situ measurements would provide the best representative data of the fluid chemistry in deep sea environment (Chin et al. 1994; Luther et al. 2001; Vuillemin et al. 2009), but only a few trace metals can be measured this way. Hence, there is an urgent need to evaluate the fractionation biases of in situ vs. ex situ filtration methods and to quantify these biases for various elements.

Several specialized samplers have been designed and employed in hydrothermal vents to collect dissolved and particulate samples for in situ filtration for various types of analyses (Huber et al. 2003; Taylor et al. 2006; Preston et al. 2011; Ussler et al. 2013), including the analysis of dissolved and particulate Fe (Kádár et al. 2005; Sarradin et al. 2008; Breier et al. 2009; 2014). However, there have been no comparison of results between in situ and ex situ sample processing methods.

Here, we provide new data from the hydrothermal mixing zone to evaluate the impact of the filtration method (in situ vs. ex situ) on the dissolved-particulate partitioning of 12 elements (Mg, Li, Mn, U, V, As, Ba, Fe, Zn, Cd, Pb and Cu). Kádár et al. (2005) also explored this comparative approach, but did not quantitatively assess the particulate phase 
because only sweeping electronic microscopy was used to determine the chemical composition of particles. Furthermore, the alteration of the dissolved phase due to ex situ filtration was not estimated. Our first objective was to quantify the biases in the assessment of the dissolved and particulate phases potentially induced by ex situ filtration methods using in situ filtration as a baseline. For each studied metal, we then determined whether it is imperative to filter fluids in situ or whether ex situ filtration can be acceptable. Our data could guide future studies by indicating the bias introduced by ex situ filtration on the chemical speciation of metals.

\section{Materials and methods}

\subsection{Study area}

This study was conducted during the MoMARSAT 2012 cruise, on the French oceanographic research vessel Thalassa with the ROV Victor 6000. The cruise focused on deep-sea EMSOAzores observatory maintenance (SEAMON E/W, Tempo and BOREL buoy) located within the Lucky Strike hydrothermal field, on the Mid-Atlantic Ridge (MAR) $\left(37^{\circ} 17^{`} \mathrm{~N}\right)$ (Colaço et al. 2011). In the Lucky Strike field, vent sites are distributed around a lava lake at depths of between 1650 and $1750 \mathrm{~m}$ (Fouquet et al. 1995). The maximum temperature recorded for the endmember fluid at this location is $324^{\circ} \mathrm{C}$ (Charlou et al. 2000). Water samples were collected on a vent close to the hydrothermal edifice Tour Eiffel $\left(37^{\circ} 17.29^{\prime} \mathrm{N}, 32^{\circ} 16.45^{\prime} \mathrm{W}\right)$. Samples were a colorless mixture of mid-temperature fluid $\left(\sim 70^{\circ} \mathrm{C}\right)$ and cold seawater, the first part of the mixing likely occurring in subsurface, within the permeable shallow crust. As described in Barreyre et al. (2014), this kind of discharge is akin to an intermediatetemperature outflow regime. 
111 All water samples were collected along the hydrothermal fluid-seawater mixing gradient with

112 the PEPITO sampler implemented on the ROV Victor 6000 (Sarradin et al. 2007). This 113 sampling device can sample down to $6000 \mathrm{~m}$ depth and was fitted with blood bags 114 (PVC, Baxter Fenwall 2L, sterile/NP-FP, R4R2041). Prior to use, all equipment used for sampling and filtration was rigorously washed three times with diluted hydrochloric acid (pH 2, Suprapur, Merck) and then thoroughly rinsed three times with ultrapure water (Milli-Q

117 element system). Filters were treated as above, but left overnight in diluted hydrochloric acid

118 before the ultrapure water rinse. Each sampling was performed by pumping water into a bag using an acid-cleaned (pH 2, HCl Suprapur, Merck) titanium-Tygon inlet coupled to the ROV temperature probe. Immediately after recovery of the ROV, samples were processed in the chemical lab on board the oceanographic vessel (clean lab, P 100000 ; ISO8) and pH was measured on a subsample using a Metrohm pH-meter. Measurements were carried out after daily calibration with NBS buffers $\left(\mathrm{pH} 4\right.$ and 7) at $25^{\circ} \mathrm{C}$. For this study, 17 samples were obtained from two ROV dives (sample list in Table 1). Eight of them were filtered in situ (IS samples), whereas the nine others, collected as close as possible to the IS samples, were dedicated to on-board filtration (OB samples) and, after freezing at $-20^{\circ} \mathrm{C}$, to filtration in the

127 laboratory on shore (LF samples). The OB samples were filtered in a clean room within $2 \mathrm{~h}$ of 128 recovery. Laboratory filtration was performed back on shore 18 months later; LF samples were filtered and acidified at $\mathrm{pH} 2\left(\mathrm{HNO}_{3} 65 \%\right.$, Suprapur, Merck) within $2 \mathrm{~h}$ of defrosting.

130 Blood bags were homogenized before carrying out the ex situ filtration methods. On-board 131 and laboratory filtration methods were performed under gentle vacuum $(<5$ psi) using pre132 washed mixed cellulose ester filters $(0.45 \mu \mathrm{m}, \mathrm{d} 47 \mathrm{~mm}, \mathrm{HATF}$, Millipore). The filtered 133 volumes varied among samples, ranging from 60 to $1200 \mathrm{~mL}$. Blanks were prepared on board 134 by pumping ultrapure water into a dedicated bag using the acid-cleaned titanium-Tygon inlet. 
135 Filtration blanks were also run in the laboratory. Aliquots and filters were stored in $500 \mathrm{~mL}$

136 Nalgene HDPE bottles and polystyrene petri-slides (Millipore), respectively. HDPE bottles 137 and petri-slides were previously washed with diluted nitric acid (2.5\%, Suprapur, Merck) 138 overnight and then thoroughly rinsed with ultrapure water. Petri-slides were dried under a 139 laminar flow hood.

\subsection{Analysis of the dissolved fraction}

142 Concentrations of $\mathrm{Mn}, \mathrm{Li}, \mathrm{U}, \mathrm{V}, \mathrm{As}, \mathrm{Ba}, \mathrm{Fe}$ and $\mathrm{Zn}$ were assessed by high-resolution

143 inductively coupled plasma/mass spectrometry (HR-ICP-MS, Element 2, ThermoFisher, 144 operating at the Pôle Spectrométrie Océan (PSO), Brest). Standards and samples were 145 prepared in $15 \mathrm{~mL}$ polypropylene tubes (Elkay), which were pre-cleaned using the same 146 protocol as for the HDPE bottles. The analysis of the dissolved fraction was performed after 147 dilution of the samples in a $2.5 \%$ nitric acid solution (dilution factor: 20 ). Standards of 148 dissolved elements were carried out in a solution of seawater depleted of trace metals (Safe149 S, Geotraces reference sample, 2004), and diluted 20 -fold in a $2.5 \%$ nitric acid solution to 150 match the saline matrix of the dissolved samples. These standards were then spiked with a 151 multi-element solution (AccuStandard; 29 elements; $10 \mathrm{mg} . \mathrm{L}^{-1}$ ). Measurement of $\mathrm{Mg}$

152 concentration was performed using inductively coupled plasma/atomic emission spectrometry 153 (ICP-AES, Ultima 2, Horiba Jobin Yvon, at the PSO in Brest) and specific standards were 154 prepared by diluting decreasing volumes of the Safe-S seawater $\left([\mathrm{Mg}]=53.0 \mathrm{mmol} . \mathrm{L}^{-1}\right)$ in a $1552.5 \%$ nitric acid solution. Aliquots of acidified seawater ( $\mathrm{pH} 2, \mathrm{HCl}$ Suprapur, Merck) were 156 used for the measurement of dissolved $\mathrm{Cd}, \mathrm{Pb}$ and $\mathrm{Cu}$ by constant current stripping analysis 157 (CCSA) with a mercury film electrode (Riso et al. 1997). To check the accuracy of the 158 method, certified seawater (CRM-CASS 4) was analyzed. The detection limits were 159 determined by three standard deviations of the blank and summarized in Table 1 . In our 
samples, the dissolved elements were generally well above the limit of detection (LOD) (Mn,

$161 \mathrm{Li}, \mathrm{U}, \mathrm{V}, \mathrm{As}, \mathrm{Ba}, \mathrm{Cd}$ and $\mathrm{Pb}$ ) except for $\mathrm{Cu}, \mathrm{Fe}$ and $\mathrm{Zn}$ because some samples were collected

162 close to the marine endmember of the gradient and displayed very low concentrations. For

163 ICP-MS measurements, signal drift was assessed and corrected using a standard bracketing

164 approach (one standard every five samples). Blanks were negligible when compared to the

165 dissolved concentrations because they were below the LOD for all the studied elements.

166 Dissolved elements were determined with a precision generally better than $0.5 \%(\mathrm{Mg}), 2.5 \%$

$167(\mathrm{Mn}), 4 \%(\mathrm{Li}, \mathrm{U}, \mathrm{Ba})$ or $5 \%(\mathrm{~V}) . \mathrm{Cd}, \mathrm{Pb}$ and $\mathrm{Cu}$ levels were assessed with a precision

168 generally better than 4,3 and $8 \%$, respectively. Due to their low concentrations, Fe, Zn and

169 As had measurement precisions of $18 \%, 15 \%$ and $27 \%$, respectively.

\subsection{Analysis of the particulate fraction}

172 Particulate elemental concentrations were assessed by HR-ICP-MS (Element 2,

173 ThermoFisher, operating at the PSO, Brest). The particulate fraction was available after

174 digestion of the entire filter in $4 \mathrm{~mL}$ of nitric acid $(65 \%$, Suprapur, Merck) and $1 \mathrm{~mL}$ of

175 hydrogen peroxide (30\%, Suprapur, Merck), by heating to $105^{\circ} \mathrm{C}$ for $4 \mathrm{~h}$. This acid digestion

176 procedure provides concentrations similar to those of the total digestion method $\left(\mathrm{HNO}_{3} / \mathrm{HF}\right)$,

177 except for Al (Yafa and Farmer 2006). The use of HF is generally recommended to

178 completely solubilize elements present in resistant minerals, such as aluminosilicates. As

179 hydrothermal particles are mostly made up of soluble sulfide and oxide minerals (Mottl and

180 McConachy 1990; Breier et al. 2012) that are relatively well digested with the acid digestion

181 procedure, we did not use HF. Instead, hydrogen peroxide was added to provide better

182 oxidization of particles and to limit the formation of nitrogen dioxide. The evaporation loss

183 during the digestion was checked using the gravimetric method. Certified reference material

184 (PACS-2, NRCC) was used to check digestion efficiency. Concentrations, recoveries and 
uncertainties obtained for the PACS-2 samples are summarized in Table 2. The percentage of

186 recovery was generally high for $\mathrm{As}, \mathrm{Fe}, \mathrm{Zn}, \mathrm{Cd}, \mathrm{Pb}$ and $\mathrm{Cu}(>70 \%)$, indicating an almost 187 complete digestion of particles. The remaining elements showed a lower extraction efficiency $188(>50 \%)$ because they were probably bound to more resistant minerals such as 189 aluminosilicates. Given that the amount of aluminosilicates was probably limited in our 190 hydrothermal samples, the digestion procedure that we used should be sufficient to correctly 191 solubilize the elements.

Table 2. Results of elemental determination in the certified reference material PACS-2.

\begin{tabular}{cccc}
\hline \multicolumn{2}{c}{ Concentrations $\left(\mathrm{mg}^{\left.-\mathrm{kg}^{-1}\right)}\right.$} & & \\
\hline Element & Certified values & Measured values (mean) & \% of recovery \\
\hline $\mathrm{Mg}$ & $14700 \pm 1300$ & $9294 \pm 424$ & $63 \pm 1$ \\
$\mathrm{Mn}$ & $440 \pm 19$ & $227 \pm 5$ & $52 \pm 1$ \\
$\mathrm{Li}$ & $32.2 \pm 2.0$ & $21.9 \pm 0.8$ & $68 \pm 1$ \\
$\mathrm{U}$ & $3^{\mathrm{a}}$ & $2.0 \pm 0.1$ & $52 \pm 1$ \\
$\mathrm{~V}$ & $133 \pm 5$ & $69 \pm 2$ & $52 \pm 1$ \\
$\mathrm{As}$ & $26.2 \pm 1.5$ & $22.6 \pm 1.4$ & $86 \pm 1$ \\
$\mathrm{Fe}$ & $40900 \pm 600$ & $28865 \pm 1663$ & $71 \pm 1$ \\
$\mathrm{Zn}$ & $364 \pm 23$ & $338 \pm 16$ & $93 \pm 1$ \\
$\mathrm{Ba}$ & $-\mathrm{b}$ & $599 \pm 37$ & $-\mathrm{b}$ \\
$\mathrm{Cd}$ & $2.11 \pm 0.15$ & $2.10 \pm 0.20$ & $99 \pm 1$ \\
$\mathrm{~Pb}$ & $183 \pm 8$ & $172 \pm 9$ & $94 \pm 1$ \\
$\mathrm{Cu}$ & $310 \pm 12$ & $305 \pm 33$ & $98 \pm 1$ \\
\hline
\end{tabular}

a Uncertainty not provided

${ }^{\mathrm{b}}$ Not available

192 Filter blanks did not significantly affect the measurements of particulate concentrations after

193 digestion, in agreement with the trace metal blanks previously conducted by Planquette and

194 Sherrell (2012) on this filter membrane. The analysis of the particulate fraction was

195 performed after a 1:20 dilution of the digested samples in ultrapure water (final concentration:

$1962.5 \%$ nitric acid). The particulate standards were prepared from the aforementioned multi-

197 element stock solution in a $2.5 \%$ nitric acid solution. From filtration to the ICP analysis, the

198 analytical error calculated on PACS-2 was generally better than $10 \%$. 


\section{Results}

\subsection{Characterization of the sampled mixing zone}

202 The total $\mathrm{Mn}\left(\mathrm{Mn}_{\mathrm{T}}\right.$, equal to the sum of dissolved $\mathrm{Mn}\left(\mathrm{Mn}_{\mathrm{d}}\right)$ and particulate $\left.\mathrm{Mn}\left(\mathrm{Mn}_{\mathrm{p}}\right)\right)$

203 concentration was used as the mixing indicator. Total Mn concentrations ranged from 0.02 to $20416.08 \mu \mathrm{M}$ (seawater: $\sim 0.5 \mathrm{nM}$ at $1700 \mathrm{~m}$ depth, (Yeats et al. 1992)). Based on the 205 conservative mixing behavior of Mn (James and Elderfield 1996), the proportion of

206 hydrothermal fluid in the sampled area can be estimated from the concentration of $\mathrm{Mn}$ in the 207 hydrothermal endmember fluid at the same site $(289 \mu \mathrm{M}$; Charlou et al. 2000). Hence, our 208 samples covered some of the mixing zone, where the hydrothermal fluid contribution 209 amounted to approximately $0.01 \%$ to $6 \%$. Temperature was in the range of 4 to $64^{\circ} \mathrm{C}$, with 210 median values below $50^{\circ} \mathrm{C}$. The organization of samples according to increasing $\mathrm{Mn}_{\mathrm{T}}$ values 211 clearly shows greater variability in temperature in Mn-rich samples (Fig. 1). This higher 212 variability may be due to the greater fraction of hot hydrothermal fluid captured during 213 sampling, possibly enhanced by turbulent mixing with seawater. The dissolved and particulate 214 concentrations measured in all samples (IS, OB and LF) are listed in Table 1. The 215 dissolved/particulate partitioning of all the elements as a function of $\mathrm{Mn}_{\mathrm{T}}$ are shown in Fig. 2. 216 


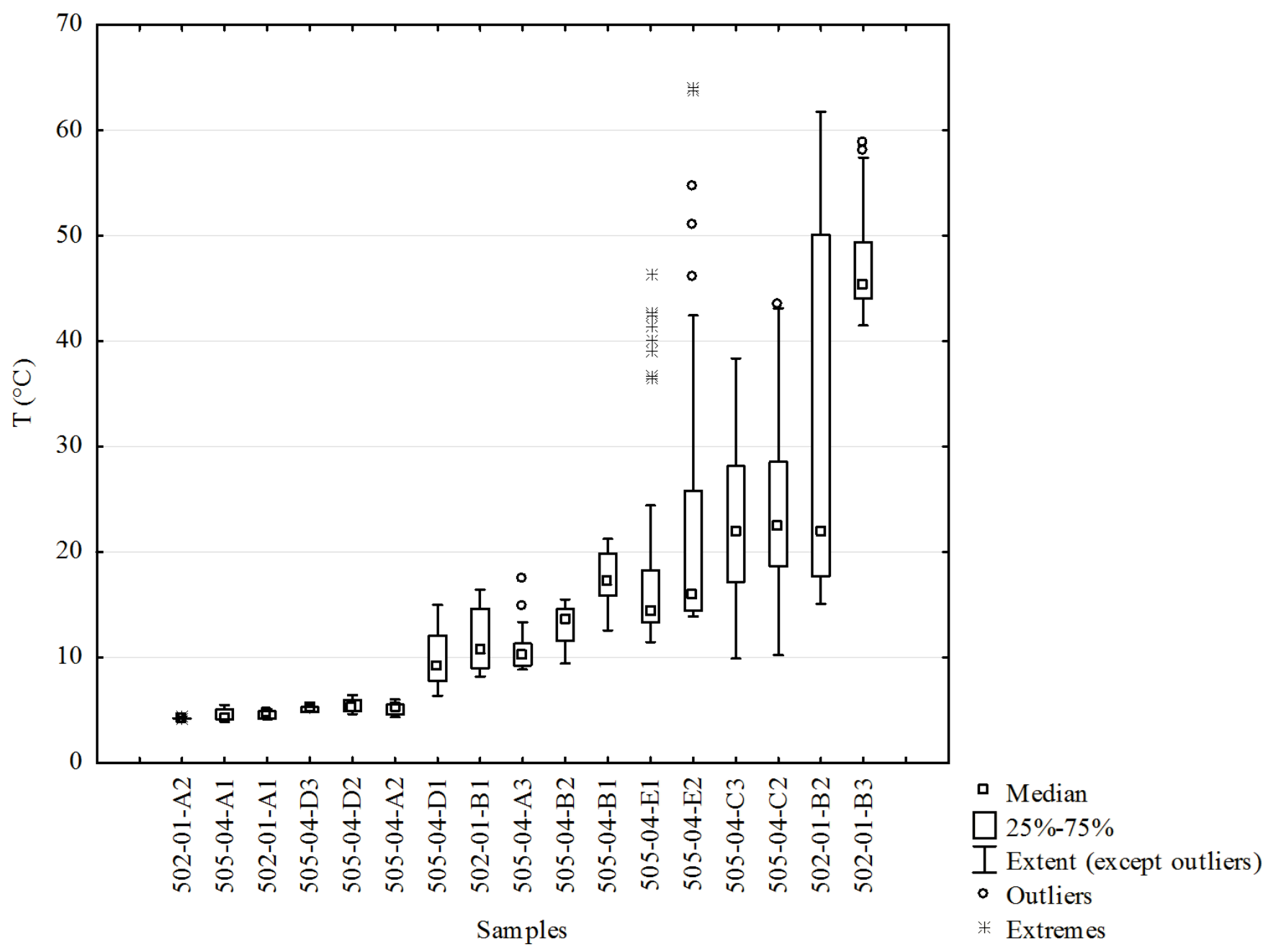

Fig. 1. Ranges of temperature recorded during the 3 minutes of each sampling performed in the study area. Samples are classified by ascending order of $\mathrm{Mn}_{\mathrm{T}}$ concentrations. Sample name includes the number of the dive (e.g. 502-01) and the number of the blood bag used for sampling (e.g. A2).

\subsection{Concentration changes after $e x$ situ filtration}

219 Four different groups of elements were discerned according to the predominance of the

220 dissolved or the particulate pools and the degree of physicochemical changes caused by $e x$

221 situ filtration. The first group includes $\mathrm{Mn}, \mathrm{Mg}$ and $\mathrm{Li}$ because their dissolved concentrations

222 dominated their particulate concentrations regardless of the filtration method and were the

223 least affected by ex situ filtration. U, V and As were grouped together because they showed

224 similar levels of concentrations, with a predominance of the dissolved pool and similar 
patterns of changes caused by ex situ filtration. The third group clusters $\mathrm{Fe}, \mathrm{Zn}$ and $\mathrm{Ba}$ which generally showed a predominance of the dissolved pool under in situ conditions and great variability of their dissolved/particulate partitioning after ex situ filtration. The last group includes $\mathrm{Cd}, \mathrm{Pb}$ and $\mathrm{Cu}$ which were mostly found in the particulate phase regardless of the filtration method used. Results obtained for each group are presented in the next four sections.

\subsubsection{Mn, $\mathrm{Mg}$ and $\mathrm{Li}$}

The in situ concentrations of dissolved Mn ranged from 0.12 to $14.12 \mu \mathrm{M}$. Similar dissolved levels were measured after on-board and laboratory filtration, ranging from 0.02 to $16.08 \mu \mathrm{M}$ and from 0.12 to $15.45 \mu \mathrm{M}$, respectively (Table 1). Particulate concentrations generally remained below $0.02 \mu \mathrm{M}$ (LOD) when performing in situ and on-board filtration, except for the sample 505-04-E2-OB whose particulate Mn was three times greater than the LOD. However, most samples filtered after freezing (6/9) showed particulate concentrations that were 2 to 45 times greater than the LOD (Table 1). The increase in the particulate pool observed should therefore be offset by a decrease in the dissolved concentrations, with the total metal concentrations remaining constant. The underestimation of the dissolved pool was clearly observed when plotting the dissolved/particulate partitioning of $\mathrm{Mn}$, especially after

freezing (Fig. 2). Compared with in situ conditions in which dissolved Mn accounted for more than $99 \%$ of total $\mathrm{Mn}$, the contribution of dissolved Mn was lower after on-board filtration, being decreased by of 0.0 to $3.0 \%$. In samples filtered after freezing, the contribution of dissolved Mn was underestimated by 0.0 to $7.0 \%$.

The in situ concentrations of dissolved $\mathrm{Mg}$ ranged from 46.7 to $50.6 \mathrm{mM}$ and similar levels were measured with the other filtration methods (Table 1). The in situ concentrations of particulate $\mathrm{Mg}$ ranged from 21 to $42 \mu \mathrm{M}$. Although similar concentrations were found with 
on-board filtration (26 to $56 \mu \mathrm{M}$ ), particulate concentrations of $\mathrm{Mg}$ were clearly higher after 250 laboratory filtration (33 to $205 \mu \mathrm{M})$.

251 The in situ concentrations of dissolved Li ranged from 24.8 to $41.5 \mu \mathrm{M}$ (Table 1). As for

252 dissolved $\mathrm{Mg}$, similar levels were found with on-board and laboratory filtration methods, 253 ranging from 26.7 to $46.3 \mu \mathrm{M}$ and from 26.7 to $45.2 \mu \mathrm{M}$, respectively. Particulate 254 concentrations of $\mathrm{Li}$ were generally below the LOD except for five samples filtered in the 255 laboratory, which were up to five times greater than the LOD.

256 The dissolved/particulate partitioning of $\mathrm{Mg}$ and Li generally changed little with the ex situ 257 filtration methods (Fig. 2). Compared to in situ conditions in which dissolved $\mathrm{Mg}$ and $\mathrm{Li}$ 258 accounted for more than $99.9 \%$ of total $\mathrm{Mg}$ and $\mathrm{Li}$, the contribution of dissolved $\mathrm{Mg}$ and $\mathrm{Li}$ 259 after on-board filtration was underestimated by only 0.0 to $0.1 \%$ and 0.0 to $0.5 \%$, 260 respectively. After freezing, the underestimation increased up to $0.3 \%$ and $4.0 \%$ for dissolved $261 \mathrm{Mg}$ and Li, respectively.

\subsection{2. $\mathrm{U}, \mathrm{V}$ and $\mathrm{As}$}

264 The in situ concentrations of dissolved U, V and As ranged from 0.010 to $0.014 \mu \mathrm{M}$, 0.025 to $0.031 \mu \mathrm{M}$ and 0.03 to $0.04 \mu \mathrm{M}$, respectively (Table 1 ). Very similar concentrations were obtained after on-board or laboratory filtration, indicating limited differences at first 267 glance.

268 Particulate concentrations of U, V and As were generally below the LOD for in situ and on269 board filtration methods, with the exception of sample 505-04-E2-OB in which particulate V 270 and As were two and three times greater than the LOD, respectively. However, for most 271 samples filtered in the laboratory (6/9), particulate concentrations of $U$ and $V$ were up to 272 seven and four times greater than the LOD, respectively. A similar trend was observed for 
273 particulate As, which was 2 to 14 times greater than the LOD after freezing in three of the 274 nine samples.

275 The dissolved/particulate partitioning of U, V and As also appeared to be affected by ex situ

276 filtration (Fig. 2). Compared to in situ conditions in which dissolved U, V and As accounted 277 for more than $99 \%, 96 \%$ and $80 \%$ of total U, V and As, the contribution of these dissolved 278 elements after on-board filtration was underestimated by 0.0 to $0.4 \%, 0.0$ to $10 \%$ and 2792.0 to $30 \%$, respectively. For samples filtered after freezing, the contribution of dissolved U, $280 \mathrm{~V}$ and As was decreased by 0.0 to $30 \%, 0.0$ to $20 \%$ and 0.0 to $80 \%$, respectively.

\subsubsection{Fe, $\mathrm{Zn}$ and $\mathrm{Ba}$}

The in situ concentrations of dissolved Fe ranged from $<$ LOD to $7.46 \mu \mathrm{M}$ (Table 1). Samples collected at temperatures greater than $10^{\circ} \mathrm{C}$ showed micromolar concentrations $(>3 \mu \mathrm{M})$. In this hotter part of the mixing gradient, the dissolved concentrations were much lower for samples filtered on-board and after freezing. They were generally lower than $1 \mu \mathrm{M}$ after on-

287 board filtration and below the LOD after freezing.

288 The in situ concentrations of dissolved $\mathrm{Zn}$ ranged from 0.64 to $1.23 \mu \mathrm{M}$ (Table 1). As observed for dissolved Fe, concentrations of dissolved $\mathrm{Zn}$ measured in Mn-rich samples $290\left(\mathrm{Mn}_{\mathrm{T}}>\sim 5 \mu \mathrm{M}\right)$ dramatically decreased after ex situ filtration. Although concentrations near $2911 \mu \mathrm{M}$ were measured for samples filtered in situ, levels of dissolved $\mathrm{Zn}$ found in those filtered 292 on board and after freezing became close to or below the LOD $(0.1 \mu \mathrm{M})$.

293 The in situ concentrations of dissolved Ba ranged from 0.11 to $3.57 \mu \mathrm{M}$ (Table 1). Although 294 the decrease in the dissolved concentrations was initially less obvious, concentrations were 295 lower after on-board and laboratory filtration (0.06 to $2.36 \mu \mathrm{M}$ and 2960.06 to $1.89 \mu \mathrm{M}$, respectively). 
297 The in situ concentrations of particulate Fe, $\mathrm{Zn}$ and $\mathrm{Ba}$ ranged from $<\mathrm{LOD}$ to $1.62 \mu \mathrm{M}$, $298<$ LOD to $3.42 \mu \mathrm{M}$ and $<$ LOD to $1.39 \mu \mathrm{M}$, respectively. Due to the decrease in the dissolved 299 fraction, the particulate concentrations increased in ex situ filtration, especially for Fe and Zn. 300 Particulate concentrations of $\mathrm{Fe}$ and $\mathrm{Zn}$ after on-board filtration ranged from $301<$ LOD to $11.9 \mu \mathrm{M}$ (mean: $2.6 \mu \mathrm{M}$ ) and from $\quad<$ LOD to $40.1 \mu \mathrm{M}$ (mean: $5.8 \mu \mathrm{M}$ ), 302 respectively. For samples filtered after freezing, concentration ranges were wider because 303 particulate $\mathrm{Fe}$ and $\mathrm{Zn}$ ranged from <LOD to $92.2 \mu \mathrm{M}$ (mean: $15.9 \mu \mathrm{M}$ ) and from 3040.14 to $140 \mu \mathrm{M}$ (mean: $16.6 \mu \mathrm{M}$ ), respectively. The increase in particulate Ba was restricted: 305 concentrations after on-board and laboratory filtration ranged from $<$ LOD to $2.02 \mu \mathrm{M}$ and 306 from $<$ LOD to $4.94 \mu \mathrm{M}$, respectively.

307 These changes in dissolved and particulate $\mathrm{Ba}, \mathrm{Fe}$ and $\mathrm{Zn}$ after ex situ filtration were also 308 clearly observed in Fig. 2. Compared with in situ conditions, dissolved Fe, Zn and Ba after 309 on-board filtration were underestimated in the range of 2.0 to $96 \%, 1.0$ to $99 \%$ and 3100.0 to $34 \%$, respectively. After freezing, dissolved Fe, $\mathrm{Zn}$ and Ba decreased by 94 to $100 \%$, 31120 to $100 \%$ and 2.0 to $70 \%$, respectively. 

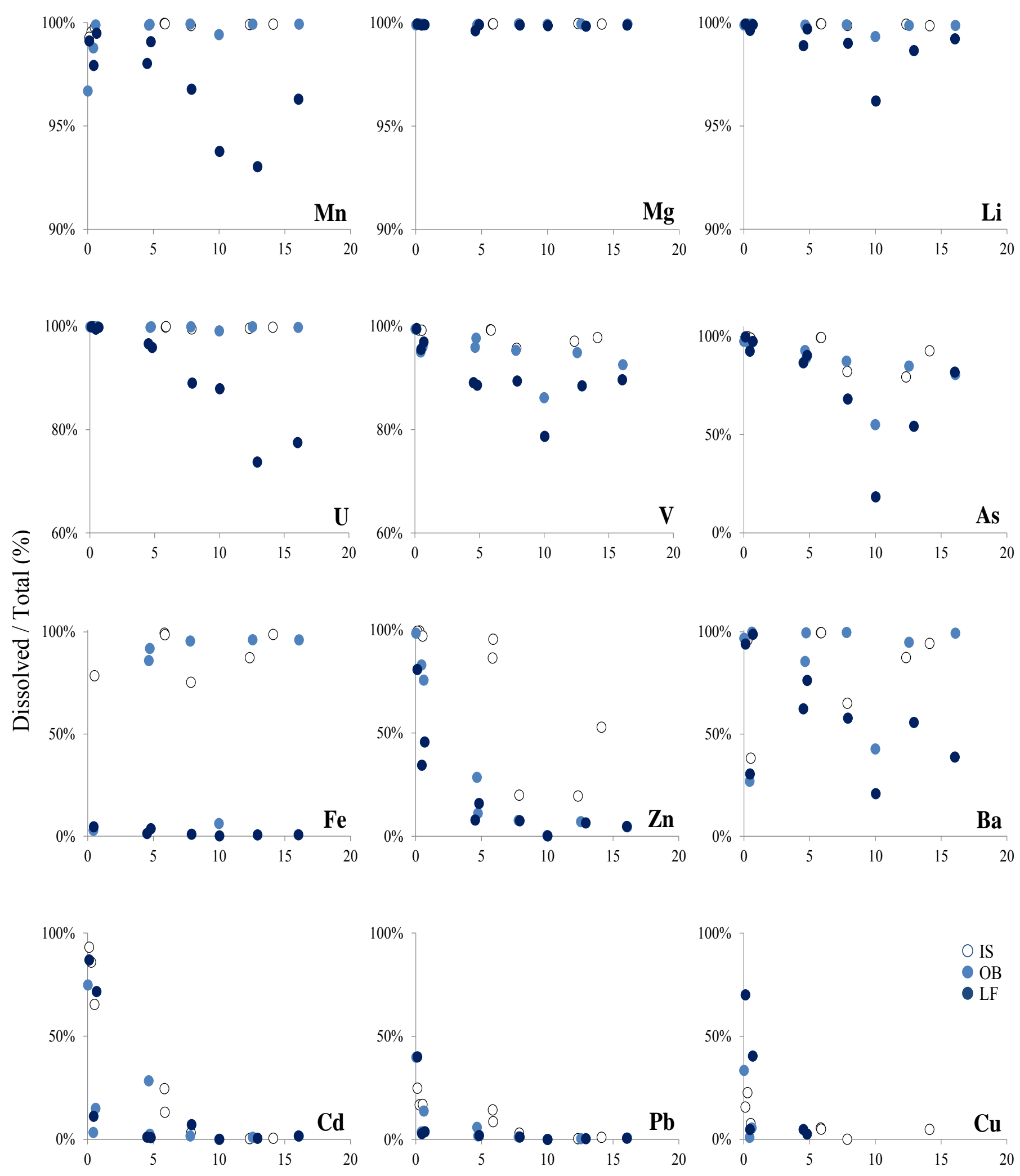

$\operatorname{MnT}(\mu \mathrm{M})$

Fig. 2. Contribution of the dissolved phase (\%) to total metal concentrations as a function of $\mathrm{Mn}_{\mathrm{T}}(\mu \mathrm{M})$. Dots represent the dissolved phase: white circles refer to in situ filtration (IS), blue circles to on-board filtration (OB) and dark blue circles to laboratory filtration, after freezing (LF). The scale for the contribution of dissolved $\mathrm{Mn}, \mathrm{Li}, \mathrm{Mg}, \mathrm{U}$ and $\mathrm{V}$ was magnified to better show effects/differences potentially induced by ex situ filtration. 
318 The in situ concentrations of dissolved and particulate $\mathrm{Cd}, \mathrm{Pb}$ and $\mathrm{Cu}$ were observed at 319 subnanomolar to nanomolar levels. The in situ concentrations and those measured after ex situ 320 filtration were generally close to the LOD, indicating that modifications in the dissolved and 321 particulate phases were difficult to assess. The only exception was for concentrations of 322 dissolved $\mathrm{Pb}$, for which a significant decrease of almost one order of magnitude was observed 323 for on-board and laboratory filtration (Table 1).

324 Our data also indicated that the dissolved/particulate partitioning changed with ex situ 325 filtration. For samples filtered in situ, the contribution of the dissolved fraction tended to 326 increase with the dilution of the hydrothermal fluid, reaching a maximum level at the lowest $327 \mathrm{Mn}_{\mathrm{T}}$ levels (Fig. 2). The increase ranged from few percentage points at $328 \mathrm{Mn}_{\mathrm{T}}=14 \mu \mathrm{M}$ to $\sim 90 \%, \sim 25 \%$ and $\sim 20 \%$ at $\mathrm{Mn}_{\mathrm{T}}=0.12 \mu \mathrm{M}$ for $\mathrm{Cd}, \mathrm{Pb}$ and $\mathrm{Cu}$, respectively. 329 This pattern was weaker for ex situ filtration, which generally caused an underestimation of 330 the contribution of the dissolved pool in the coldest part of the gradient.

\section{Discussion}

Our results highlighted an underestimation of dissolved metal concentrations accompanied by

334 an overestimation of the particulate phase when ex situ filtration is performed. The 335 modifications of the dissolved and particulate pools varied according to the element. Below, 336 we inventory the elements that can be properly assessed using ex situ — shipboard or 337 laboratory - filtration methods. We then discuss the chemical processes that may explain the 338 observed biases. 
341 Of the three filtration methods performed, the in situ method is of course the best one for

342 obtaining representative data on metal chemistry in the deep-sea environment. The degree of 343 sensitivity of the dissolved and particulate pools of each sample after ex situ filtration was 344 therefore assessed using the in situ filtration as a baseline. Many laboratories perform on345 board filtration to assess metal concentrations, requiring a study of its suitability for properly 346 characterizing the dissolved and particulate phases. Although rarely used, filtration after 347 freezing was also interesting to investigate because it can serve as an extreme example of the 348 bias caused by freezing and delayed filtration.

349 In samples filtered on board, our results show that dissolved $\mathrm{Mn}, \mathrm{Mg}, \mathrm{Li}$ and $\mathrm{U}$ were the 350 least affected of all the elements studied: the underestimation of the dissolved phase did not 351 exceed 3\%. Hence, dissolved concentrations of $\mathrm{Mn}, \mathrm{Mg}, \mathrm{Li}$, and $\mathrm{U}$ were not significantly 352 affected by the on-board filtration method, which thus appears suitable for properly 353 characterizing the dissolved pool of these four elements. Particulate concentrations after on354 board filtration obtained for $\mathrm{Mg}$ were generally similar to the in situ concentrations and 355 generally remained below the LOD for $\mathrm{Mn}, \mathrm{Li}$ and $\mathrm{U}$ (Table 1). This pattern suggests that 356 modifications of the particulate pool for these elements are only slight, although more precise 357 quantification of the particulate concentrations is required for confirmation.

358 For V and As, limited changes occurred after on-board filtration, but our results showed that 359 the contribution of the dissolved concentrations can decrease by $10 \%$ and $30 \%$, respectively. 360 The observed underestimation was mainly driven by the single, aforementioned particle-rich 361 sample (505-04-E2-OB), explaining both maximum percentages observed. Without the 362 influence of this outlier sample, dissolved V and As after the on-board filtration would be 363 underestimated by up to $\sim 5 \%$ and $\sim 15 \%$, respectively (Fig. 2). Given these relatively high 364 percentages, the in situ filtration method is preferable for these two elements. 
The most affected elements were Fe, Zn, and Ba (Fig. 2). For some samples filtered on board,

366 the dissolved phase had mostly converted into particles (e.g. Zn), which greatly distorted the

367 initial dissolved/particulate partitioning of these elements. As mentioned above for V and As,

368 the underestimation of dissolved $\mathrm{Fe}$ and $\mathrm{Ba}$ observed can be attributed to the outlier sample

369 505-04-E2-OB. However, the percentages of underestimation still remain high even without

370 its influence, with underestimation ranging from a few percent to $\sim 30 \%$ and $\sim 96 \%$,

371 respectively (Fig. 2). Consequently, the routine use of the in situ filtration method is strongly

372 recommended for the accurate quantification of the dissolved and particulate phases of these

373 three elements.

374 Regarding dissolved and particulate $\mathrm{Cd}, \mathrm{Pb}$ and $\mathrm{Cu}$, results are less conclusive although they 375 suggest that shipboard filtration underestimates the dissolved phase (Table 1, Fig. 2). This

376 underestimation was clear for dissolved $\mathrm{Pb}$ concentrations, which were significantly lower 377 compared with in situ filtered samples. The dissolved/particulate partitioning of $\mathrm{Cd}$ and $\mathrm{Pb}$ 378 also showed that the contribution of the dissolved pool after on-board filtration was lower in 379 the cold part of the mixing gradient (Fig. 2). As a precaution, in situ filtration should therefore 380 be preferred for proper assessment of these three elements.

381 Filtration after freezing causes a large bias in the dissolved and particulate concentrations for 382 all the elements studied (Fig. 2). Therefore, this filtration method is definitely not 383 recommended.

\subsection{On the processes occurring in ex situ filtration}

386 As the decrease in the dissolved fraction was generally counterbalanced by an increase of the 387 particulate fraction, most of the changes occurring during ex situ filtration can be attributed to 388 various precipitation/scavenging processes. Unfortunately, adsorption of the elements onto the 389 blood bags or the bottle walls cannot be fully excluded. This type of adsorption has been 
demonstrated for several elements in natural waters (Truitt and Weber 1979). However, the

391 relatively low $\mathrm{pH}$ of our samples, combined with the rapidity with which the on-board

392 filtration was carried out after retrieval $(<2 \mathrm{~h})$ and the storage of filtered samples in acid-

393 cleaned PVC bags or HDPE bottles, should limit losses due to adsorption (Batley and Gardner 394 1977).

395 To better understand precipitation/scavenging processes, correlations between all 396 particulate elements were investigated and are summarized in Table 3. The statistically 397 significant correlations ( $\mathrm{p}$-value $<0.05$ ) discriminate two main groups of highly correlated 398 elements. The first one groups particulate $\mathrm{Mn}, \mathrm{Li}, \mathrm{U}, \mathrm{V}, \mathrm{As}, \mathrm{Ba}$ and Fe, whereas the second 399 one is composed of $\mathrm{Cd}, \mathrm{Pb}, \mathrm{Cu}$ and $\mathrm{Zn}$. Other sub-groups were also involved but correlations, 400 though statistically significant, were less pronounced (Table 3). Here, we only focus on the 401 two aforementioned groups.

402 The high positive correlations between particulate $\mathrm{Mn}, \mathrm{Li}, \mathrm{U}, \mathrm{V}, \mathrm{As}, \mathrm{Ba}$ and Fe suggest 403 that dissolved Mn, Li, U, V, As and Ba may have been primarily scavenged by Fe-oxide 404 particles during the ex situ filtration process. Dissolved Fe levels from hydrothermal vents can 405 be affected by two chemical precipitation processes: entrapment by sulfide particles and 406 formation of Fe-oxyhydroxides (Mottl and McConachy 1990; Rudnicki and Elderfield 1993). 407 The co-precipitation of Fe(II) in polymetallic sulfide phases occurs immediately upon fluid 408 discharge, whereas Fe-oxide particles are formed later in more oxidizing conditions (Rudnicki 409 and Elderfield 1993). Each precipitation process has been suggested to account for $80-90 \%$ 410 and $10-20 \%$ of dissolved Fe removal, respectively (German et al. 2002). Once formed, small 411 Fe-rich sulfide particles are exported in the buoyant and neutrally buoyant plume (Yücel et al. 412 2011; Breier et al. 2012), showing that reduced and oxidized particles can coexist in the 413 diluted plume. This two-stage precipitation process occurs in hot focused black smokers 414 where sulfides are abundant. However, our samples come from an intermediate-temperature 
415 vent that emits a colorless and translucent mixture of hot hydrothermal fluid $\left(\sim 70^{\circ} \mathrm{C}\right)$ and

416 cold seawater. Given that the first part of mixing probably occurs in the shallow crust, most of 417 the sulfides would have precipitated in the subsurface. The large underestimations of 418 dissolved Fe observed throughout the ex situ filtration process should therefore mainly come 419 from oxidative precipitation such as Fe-oxyhydroxide formation. Our samples may thus be 420 made up of pre-existing Fe-oxide particles that formed before sampling, but also of newly 421 formed $\mathrm{Fe}$-oxides that may have precipitated post-sampling.

422 Away from vent sources, dissolved $\mathrm{Mn}$ is commonly known to undergo slow scavenging 423 processes by suspended particles (Cowen et al. 1990; Feely et al. 1994), which are enhanced 424 by Mn(II)-oxidizing bacteria (Mandernack and Tebo 1993). German et al. (1991) also 425 observed a correlation $\left(\mathrm{r}^{2}=0.610\right)$ between particulate $\mathrm{Mn}$ and $\mathrm{Fe}$ in the diluted plume, 426 suggesting progressive scavenging of dissolved Mn onto Fe-rich particulate phases, which are mainly Fe-oxyhydroxide particles. Dissolved $\mathrm{Ba}$ has been suggested to undergone similar scavenging processes as those reported for dissolved Mn (Feely et al. 1994). This element 429 could therefore be scavenged by Fe-oxyhydroxide particles.

430 Other precipitation processes not revealed by the correlations may explain the modifications 431 of the dissolved and particulate pool observed for $\mathrm{Mn}$ and $\mathrm{Ba}$. Regarding $\mathrm{Mn}$, precipitation of $432 \mathrm{MnO}_{2}$ may occur in our samples, assuming that oxygen levels increased slightly during ex situ 433 filtration. In the case of $\mathrm{Ba}$, precipitation of barite may occur because our samples are a 434 mixture of fluid and entrained sulfate-rich seawater (Charlou et al. 2000).

435 As observed for $\mathrm{Mn}$ and $\mathrm{Ba}$, scavenging processes from seawater enhanced by physico436 chemical changes $\left(\mathrm{T}, \mathrm{p}, \mathrm{O}_{2}\right)$ during retrieval and freezing/defrosting of samples may explain 437 the changes in phase distribution observed for U, V and As. Previous studies have highlighted 438 pronounced linear correlations of particulate U, V and As with particulate Fe, suggesting that 
439 Fe-oxyhydroxide particles rapidly scavenge dissolved U, V and As from the seawater 440 (German et al. 1991; Feely et al. 1994; Kadko et al. 1994; Breier et al. 2012).

441 The high correlations between particulate $\mathrm{Zn}, \mathrm{Cd}, \mathrm{Pb}$, and $\mathrm{Cu}$ suggest that $\mathrm{Cd}, \mathrm{Pb}$ and $\mathrm{Cu}$ 442 precipitated in a wurtzite or sphalerite phase. This supposition is supported by previous 443 reports of the formation of $\mathrm{Cd}, \mathrm{Pb}, \mathrm{Cu}$ and $\mathrm{Zn}$ precipitates in sulfide minerals, suggesting a 444 co-precipitation of dissolved $\mathrm{Cd}, \mathrm{Pb}, \mathrm{Cu}$ and $\mathrm{Zn}$ directly from vent fluids (Trocine and Trefry 445 1988; German et al. 1991; Sarradin et al. 2008; Breier et al. 2012).

446 In addition, nanoparticle aggregation mechanisms, such as flocculation, may explain the 447 observed changes in the dissolved and particulate pools. Recent studies on particle 448 morphology all observed a natural aggregation of particles in their in situ hydrothermal 449 samples (Breier et al. 2012; Toner et al. 2012). If there is a limited artefact of in situ filtration 450 on the aggregation mechanism (Breier et al. 2012), ex situ filtration may enhance this natural 451 process, potentially explaining the overestimation of the particulate pool. A characterization 452 of the nature of particles is required to confirm these hypotheses on these potentially 453 occurring precipitation processes. 


\section{Conclusion}

We assessed the impact of the filtration method (in situ vs. ex situ) on the dissolved/particulate partitioning of 12 elements. Depending on the metal considered, a decrease in dissolved metal concentrations, counterbalanced by an increase in particle levels, occur in ex situ filtration. Four groups of elements showing similar patterns of changes in their dissolved and particulate concentrations were described: 1) Mn, Mg and Li; 2) U, V and As; 3) $\mathrm{Fe}, \mathrm{Zn}$ and $\mathrm{Ba}$; 4) $\mathrm{Cd}, \mathrm{Pb}$ and $\mathrm{Cu}$. On-board filtration appears sufficient to properly assess dissolved and particulate $\mathrm{Mn}, \mathrm{Mg}, \mathrm{Li}$, and $\mathrm{U}$ with very limited changes in the concentrations compared with those measured after in situ filtration. However, on-board filtration is not suitable for accurately measuring the dissolved and particulate concentrations of $\mathrm{V}, \mathrm{As}, \mathrm{Fe}, \mathrm{Zn}, \mathrm{Ba}, \mathrm{Cd}, \mathrm{Pb}$ and $\mathrm{Cu}$, for which there were large underestimations of the particulate pool. In situ filtration should therefore be used routinely to accurately characterize the dissolved and particulate phases of these elements. Laboratory filtration is definitely not recommended because it causes large biases in concentrations. Scavenging of metals by Feoxyhydroxide particles may explain the changes observed for $\mathrm{Mn}, \mathrm{U}, \mathrm{V}, \mathrm{As}$ and $\mathrm{Ba}$. Particulate $\mathrm{Cd}, \mathrm{Pb}, \mathrm{Cu}$ and $\mathrm{Zn}$ were highly correlated suggesting co-precipitation of these metals in a wurtzite or sphalerite phase.

Overall, our results clearly improve our understanding of the impact caused by ex situ filtration on the dissolved and particulate distribution of metals. Therefore, all chemical speciation data based on shipboard filtration already described in the literature may not fully represent the original species found in the deep-sea environment. This bias may have relevant implications for the computation of hydrothermal metal export fluxes to the deep ocean. 


\section{Acknowledgments}

482 We would like to thank Mathilde Cannat, chief scientist of the MoMARSAT 2012 cruise, the $483 \mathrm{R} / \mathrm{V}$ Thalassa crew and the Victor $6000 \mathrm{ROV}$ pilots for their assistance and constant support. 484 We are grateful to Virginie Tanguy for her excellent work during this sampling campaign. We 485 also acknowledge Claire Bassoulet, Céline Liorzou and Marie-Laure Rouget for their helpful 486 assistance in instrumental analyses. This work was carried out with the financial support of 487 Labex Mer (Ironman project, axe 3, IUEM, Brest). It was also supported by a doctoral grant 488 from MENRT and IFREMER. We are grateful to Dr. Carolyn Engel-Gautier (Chrysalide, 489 Finistere, France) for her linguistic editing. Finally, we wish to acknowledge three anonymous 490 reviewers for their helpful and constructive comments. 


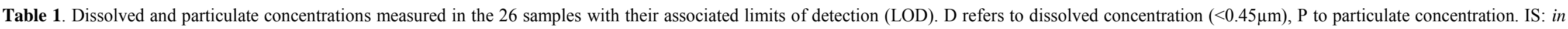

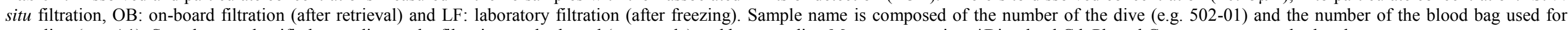
sampling (e.g. A1). Samples are classified according to the filtration method used (gray-scale) and by ascending MnT concentration. *Dissolved Cd, $\mathrm{Pb}$ and $\mathrm{Cu}$ were at nanomolar levels.

\begin{tabular}{|c|c|c|c|c|c|c|c|c|c|c|c|c|c|c|c|c|c|c|c|c|c|c|c|c|c|c|}
\hline \multirow[t]{4}{*}{ Sample } & \multirow[t]{4}{*}{$\mathrm{T}^{\circ} \mathrm{C}$} & \multirow[t]{3}{*}{$\mathrm{pH}$} & \multirow{2}{*}{\multicolumn{2}{|c|}{$\begin{array}{l}\mathrm{Mn} \\
\mu \mathrm{M}\end{array}$}} & \multicolumn{3}{|c|}{$\mathrm{Mg}$} & \multirow{2}{*}{$\begin{array}{c}\mathrm{Li} \\
\mu \mathrm{M}\end{array}$} & \multirow{2}{*}{\multicolumn{2}{|c|}{$\begin{array}{c}\mathrm{U} \\
\mu \mathrm{M}\end{array}$}} & \multirow{2}{*}{\multicolumn{2}{|c|}{$\begin{array}{c}\mathrm{V} \\
\mu \mathrm{M}\end{array}$}} & \multirow{2}{*}{\multicolumn{2}{|c|}{$\begin{array}{l}\text { As } \\
\mu \mathrm{M}\end{array}$}} & \multirow{2}{*}{\multicolumn{2}{|c|}{$\begin{array}{c}\mathrm{Fe} \\
\mu \mathrm{M}\end{array}$}} & \multirow{2}{*}{\multicolumn{2}{|c|}{$\begin{array}{c}\mathrm{Zn} \\
\mu \mathrm{M}\end{array}$}} & \multirow{2}{*}{\multicolumn{2}{|c|}{$\begin{array}{c}\mathrm{Ba} \\
\mu \mathrm{M}\end{array}$}} & \multirow{2}{*}{\multicolumn{2}{|c|}{$\begin{array}{l}\mathrm{Cd}^{*} \\
\mathrm{nM}\end{array}$}} & \multirow{2}{*}{\multicolumn{2}{|c|}{$\begin{array}{l}\mathrm{Pb}^{*} \\
\mathrm{nM}\end{array}$}} & \multirow{2}{*}{\multicolumn{2}{|c|}{$\begin{array}{l}\mathrm{Cu}^{*} \\
\mathrm{nM}\end{array}$}} \\
\hline & & & & & $\mathrm{mM}$ & $\mu \mathrm{M}$ & & & & & & & & & & & & & & & & & & & & \\
\hline & & & D & $\mathrm{P}$ & D & $\mathrm{P}$ & D & $\mathrm{P}$ & D & $\mathrm{P}$ & D & $\mathrm{P}$ & D & $\mathrm{P}$ & D & $\mathrm{P}$ & D & $\mathrm{P}$ & D & $\mathrm{P}$ & D & $\mathrm{P}$ & D & $\mathrm{P}$ & D & $\mathrm{P}$ \\
\hline & & OD & 0.004 & 0.02 & 0.02 & 3 & 0.06 & 0.3 & 0.0001 & 0.0004 & 0.003 & 0.002 & 0.001 & 0.009 & 0.2 & 0.05 & 0.1 & 0.04 & 0.01 & 0.005 & 0.01 & 0.5 & 0.01 & 2 & 0.7 & 10 \\
\hline 505-04-A1-IS & 4.6 & 7.6 & 0.12 & $<\mathrm{LOD}$ & 50.6 & 32 & 25.3 & $<$ LOD & 0.014 & $<$ LOD & 0.031 & $<\mathrm{LOD}$ & 0.03 & $<$ LOD & $<\mathrm{LOD}$ & $<\mathrm{LOD}$ & 0.66 & $<\mathrm{LOD}$ & 0.11 & $<\mathrm{LOD}$ & 0.20 & $<\mathrm{LOD}$ & $<$ LOD & $<\mathrm{LOD}$ & 0.8 & $<\mathrm{LOD}$ \\
\hline 502-01-A1-IS & 4.6 & 7.5 & 0.28 & $<\mathrm{LOD}$ & 49.4 & 37 & 24.8 & $<$ LOD & 0.013 & $<$ LOD & .028 & $<$ LOD & 0.04 & $<$ LOD & $<$ LOD & 0.05 & 1.04 & $<$ LOD & 0.16 & 0.01 & 0.13 & $<$ LOD & 0.02 & $<$ LOD & 2.0 & $<$ LOD \\
\hline 505-04-D2-IS & 5.4 & 7.3 & 0.53 & $<\mathrm{LOD}$ & 48.6 & 42 & 25.4 & $<$ LOD & 0.014 & $<\mathrm{LOD}$ & .028 & $<\mathrm{LOD}$ & 0.03 & $<\mathrm{LOD}$ & 0.23 & 0.06 & 1.23 & $<\mathrm{LOD}$ & 0.28 & 0.44 & 0.08 & $<$ LOD & 0.05 & $<$ LOD & $<$ LOD & $<$ LOD \\
\hline 505-04-B2-IS & 13 & 6.1 & 5.88 & $<\mathrm{LOD}$ & 48.7 & 27 & 31.4 & $<\mathrm{LOD}$ & 0.013 & $<\mathrm{LOD}$ & 0.028 & $<\mathrm{LOD}$ & 0.04 & $<\mathrm{LOD}$ & 3.90 & 0.06 & 0.64 & $<\mathrm{LOD}$ & 2.02 & 0.01 & 0.05 & $<\mathrm{LOD}$ & 0.12 & $<\mathrm{LOD}$ & 0.8 & 16 \\
\hline 505-04-E1-IS & 19 & 6.1 & 7.86 & $<\mathrm{LOD}$ & 46.9 & 30 & 3.5 & $<$ LOD & 0.012 & $<$ LOD & 029 & $<\mathrm{LOD}$ & 0.04 & $<\mathrm{LOD}$ & 4.93 & 1.62 & 0.85 & 3.42 & 2.59 & 1.39 & 0.23 & 6.9 & 0.28 & 9 & $<\mathrm{LOD}$ & 111 \\
\hline 505-04-C3-IS & 23 & 5.7 & 12.33 & $<\mathrm{LOD}$ & 46.7 & 21 & 38.2 & $<$ LOD & 0.010 & $<$ LOD & 025 & $<$ LOD & 0.03 & $<$ LOD & 4.43 & 0.64 & 0.69 & 2.85 & 2.66 & 0.38 & 0.02 & 4.9 & 0.03 & 10 & $<$ LOD & 48 \\
\hline 502-01-B2-IS & 34 & 4.4 & 14.12 & $<\mathrm{LOD}$ & 47.1 & 31 & 41.5 & $<$ LOD & 0.010 & $<\mathrm{LOD}$ & .028 & $<$ LOD & 0.04 & $<\mathrm{LOD}$ & 7.46 & 0.10 & 0.77 & 0.69 & 3.57 & 0.21 & 0.02 & 3.0 & 0.07 & 1 & 2.1 & 43 \\
\hline 502-01-A2-OB & 4.2 & & 0.02 & $<\mathrm{LOD}$ & 50.3 & 56 & 26.7 & $<$ LOD & 0.014 & $<$ LOD & 0.031 & $<\mathrm{LOD}$ & 0.03 & $<\mathrm{LOD}$ & $<\mathrm{LOD}$ & $<\mathrm{LOD}$ & 0.75 & $<\mathrm{LOD}$ & 0.06 & $<\mathrm{LOD}$ & 0.18 & $<$ LOD & 0.03 & $<\mathrm{LOD}$ & 1.7 & $<\mathrm{LOD}$ \\
\hline 505-04-D3-OB & 5.1 & 7.2 & 0.44 & $<\mathrm{LOD}$ & 50.8 & 40 & 26.9 & $<$ LOD & 0.015 & $<\mathrm{LOD}$ & .029 & $<\mathrm{LOD}$ & 0.03 & $<\mathrm{LOD}$ & $<$ IOD & 0.39 & 1.31 & 0.27 & 0.21 & 0.58 & 0.01 & $<\mathrm{IOD}$ & 0.02 & $<\mathrm{LOD}$ & $<$ LOD & 12 \\
\hline $505-0$ & 5.1 & 7.3 & 0.61 & $<\mathrm{LOD}$ & 51.3 & 41 & .8 & $<$ LOD & 0.014 & $<\mathrm{LOD}$ & 31 & $<\mathrm{LOD}$ & 0.04 & $<\mathrm{LOD}$ & $<\mathrm{LOD}$ & 0 & 0.31 & 0.10 & 28 & $=200$ & 0.03 & $<\mathrm{LOD}$ & 0.02 & $\mathrm{D}$ & $\mathrm{D}$ & $<$ LOD \\
\hline 502-01-B1-OB & 12 & 6.3 & 4.73 & $<\mathrm{LOD}$ & 50.7 & 36 & 31.8 & $<$ LOD & 0.013 & $<$ LOD & 0.024 & $<\mathrm{LOD}$ & 0.03 & $<\mathrm{LOD}$ & 0.40 & $<\mathrm{LOD}$ & $<$ LOD & 0.84 & 1.26 & 0.01 & 0.02 & 0.8 & 0.02 & $<\mathrm{LOD}$ & $<$ LOD & 12 \\
\hline 505-04-B1-OB & 17 & 6.2 & 7.81 & $<\mathrm{LOD}$ & 49.0 & 26 & 4.8 & $<$ LOD & 012 & $<$ LOD & 022 & $<$ LOD & 0.04 & $<$ LOD & 0.70 & $<$ LOD & $<\mathrm{IOD}$ & 1.2 & 1.44 & $<\mathrm{I}$ & 0.02 & 1.0 & 0.02 & $<\mathrm{LOD}$ & $<$ LOD & 14 \\
\hline -OB & 22 & 5. & 9. & 0.06 & 50.1 & 42 & .6 & $<$ & 2 & $<$ & 0.023 & 0.004 & 0 & 0.03 & 0 & 1 & $<$ LOD & 4 & 1.50 & 2.02 & $<\mathrm{I}$ & 77 & 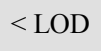 & 36 & LOD & 701 \\
\hline 505-04-C2-OB & 24 & 5.7 & 12.55 & $<\mathrm{LOD}$ & 48.4 & 31 & 40.7 & $<$ LOD & 011 & $<\mathrm{LOD}$ & 024 & $<$ LOD & 3 & $<$ LOD & 0.9 & $<$ LOD & $<$ LOD & 1.38 & 40 & 0. & 0.02 & 1.7 & $<$ LOD & 2 & $<$ LOD & $<$ LOD \\
\hline 502-01-B3-OB & 47 & 5.7 & 16.08 & $<\mathrm{LOD}$ & 47.9 & 32 & 46.3 & $<$ LOD & 0.010 & $<\mathrm{LOD}$ & 0.021 & $<\mathrm{LOD}$ & 0.03 & $<\mathrm{LOD}$ & 1.88 & 0.08 & $<$ LOD & 2.22 & 2.36 & 0.02 & 0.03 & 1.9 & 0.03 & 4 & $<$ LOD & 22 \\
\hline 502-01-A2-LF & 4.2 & & 0.12 & $<\mathrm{LOD}$ & 50.3 & 33 & 26.7 & $<$ LOD & 014 & $<$ LOD & 032 & $<$ LOD & 003 & $<$ LOD & LOD & $<\mathrm{LOD}$ & 61 & 0.1 & 0.06 & $<\mathrm{L}$ & 0.18 & $<\mathrm{I}$ & 0.03 & D & 2.6 & $<\mathrm{LOD}$ \\
\hline 505-04-D3-LF & 5.1 & & 0.46 & $<\mathrm{LOD}$ & 50.8 & 50 & 7.0 & $<$ LOD & 0.014 & $<\mathrm{LOD}$ & 033 & $<\mathrm{LOD}$ & 0.03 & $<$ LOD & $<\mathrm{LOD}$ & 0.39 & 0.81 & 15 & 1 & 04 & 0.05 & -5 & 0.02 & $-\mathrm{I}$ & 0.8 & 15 \\
\hline 505-04-A2-LF & 5.1 & & 0.69 & $<\mathrm{LOD}$ & 51.3 & 53 & 27.8 & $<$ LOD & 0.014 & $<\mathrm{LOD}$ & 030 & $<$ LOD & 0.03 & $<\mathrm{L}$ & K LOD & 0.2 & 0.16 & 0. & 0.28 & $<$ LOD & 0.16 & $<\mathrm{LOD}$ & $<$ LOD & $<\mathrm{LOD}$ & 2.2 & $<\mathrm{LOD}$ \\
\hline 505-04-D1-LF & 10 & & 4.44 & 0.09 & 52.0 & 206 & 32.2 & 0.4 & 0.013 & 0.0005 & .028 & 0.003 & 0.04 & $<\mathrm{LOD}$ & $<\mathrm{LOD}$ & 3.54 & $<$ LOD & 1.24 & 1.38 & 0.83 & 0.02 & 1.6 & $<$ LOD & 2 & 4.6 & 94 \\
\hline 502-01-B1-LF & 12 & & 4.78 & 0.04 & 50.7 & 53 & 30.8 & $<\mathrm{LOD}$ & 0.013 & 0.0006 & 026 & 03 & 0.03 & $<$ LOD & $<\mathrm{LOD}$ & 3 & 0.25 & 1.35 & 1.46 & 045 & 001 & 14 & 0.12 & 6 & $<$ LOD & 4 \\
\hline 505-04-B1-LF & 17 & & 7.66 & 0.26 & 49.0 & 58 & 5.1 & 0.4 & 0.011 & 0.0013 & (2) & 0003 & 0.04 & 0.02 & $<$ LOD & 5.27 & $<$ LOD & 1.30 & 2 & 1 & 1 01 & 12 & 0.02 & 2 & $<$ LOD & 4 \\
\hline 505-04-E2-LF & 22 & & 9.41 & 0.63 & 50.1 & 74 & 36.6 & 1.4 & 0.011 & 0.0015 & 0.028 & 0.008 & 0.03 & 0.13 & $<\mathrm{LOD}$ & 92.2 & $<\mathrm{LOD}$ & 140 & 1.30 & 4.94 & 0.01 & 261 & $<$ LOD & 111 & $<\mathrm{LOD}$ & 2330 \\
\hline 505-04-C2-LF & 24 & & 12.03 & 0.90 & 48.4 & 84 & 41.9 & 0.6 & 0.008 & 0.0029 & 0.028 & 0.004 & 0.03 & 0.03 & $<\mathrm{LOD}$ & 9.20 & $<\mathrm{LOD}$ & 1.53 & 1.89 & 1.51 & 0.01 & 1.7 & $<$ LOD & 3 & $<\mathrm{LOD}$ & 17 \\
\hline
\end{tabular}




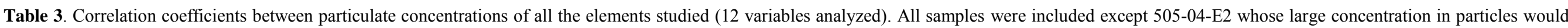

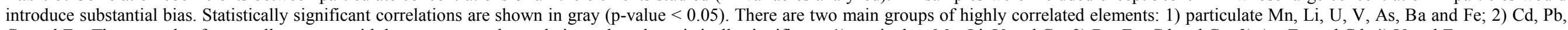

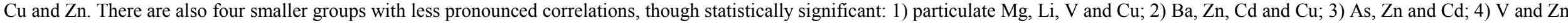

\begin{tabular}{|c|c|c|c|c|c|c|c|c|c|c|c|c|}
\hline & $\mathbf{M n}_{\mathbf{P}}$ & $\mathbf{M g}_{\mathbf{P}}$ & $\mathbf{L i}_{\mathbf{P}}$ & $\mathbf{U}_{\mathbf{P}}$ & $V_{P}$ & $\mathbf{A S P}$ & $\mathrm{Fe}_{\mathrm{P}}$ & $\mathbf{Z n}_{\mathbf{P}}$ & Bap & $\mathbf{C d}_{\mathbf{P}}$ & $\mathbf{P b}_{\mathbf{P}}$ & $\mathbf{C u p}$ \\
\hline $\mathbf{M n}_{\mathbf{P}}$ & & 0.28 & 0.89 & 0.98 & 0.67 & 0.80 & 0.90 & 0.29 & 0.76 & 0.16 & 0.09 & 0.04 \\
\hline $\mathbf{M g}_{\mathbf{P}}$ & 0.28 & & 0.61 & 0.31 & 0.58 & 0.25 & 0.37 & 0.04 & 0.30 & -0.05 & -0.10 & 0.44 \\
\hline $\mathbf{L i}_{\mathbf{P}}$ & 0.89 & 0.61 & & 0.91 & 0.84 & 0.83 & 0.87 & 0.33 & 0.73 & 0.16 & 0.10 & 0.26 \\
\hline $\mathbf{U}_{\mathbf{P}}$ & 0.98 & 0.31 & 0.91 & & 0.75 & 0.78 & 0.96 & 0.31 & 0.82 & 0.17 & 0.12 & 0.06 \\
\hline$V_{P}$ & 0.67 & 0.58 & 0.84 & 0.75 & & 0.71 & 0.81 & 0.47 & 0.69 & 0.24 & 0.26 & 0.35 \\
\hline ASP & 0.80 & 0.25 & 0.83 & 0.78 & 0.71 & & 0.70 & 0.59 & 0.60 & 0.43 & 0.38 & 0.29 \\
\hline $\mathrm{Fep}_{\mathrm{P}}$ & 0.90 & 0.37 & 0.87 & 0.96 & 0.81 & 0.70 & & 0.39 & 0.90 & 0.26 & 0.22 & 0.20 \\
\hline $\mathbf{Z n}_{\mathbf{P}}$ & 0.29 & 0.04 & 0.33 & 0.31 & 0.47 & 0.59 & 0.39 & & 0.55 & 0.87 & 0.81 & 0.67 \\
\hline Bap & 0.76 & 0.30 & 0.73 & 0.82 & 0.69 & 0.60 & 0.90 & 0.55 & & 0.48 & 0.34 & 0.42 \\
\hline Cdp & 0.16 & -0.05 & 0.16 & 0.17 & 0.24 & 0.43 & 0.26 & 0.87 & 0.48 & & 0.92 & 0.80 \\
\hline $\mathbf{P b}_{\mathbf{P}}$ & 0.09 & -0.10 & 0.10 & 0.12 & 0.26 & 0.38 & 0.22 & 0.81 & 0.34 & 0.92 & & 0.69 \\
\hline
\end{tabular}




\section{References}

Barreyre T., Escartín J., Sohn R.A., Cannat M., Ballu V. and Crawford W.C. (2014). "Temporal variability and tidal modulation of hydrothermal exit-fluid temperatures at the Lucky Strike deep-sea vent field, Mid-Atlantic Ridge." Journal of Geophysical Research 119(4): 2543-2566.

Batley G.E. and Gardner D. (1977). "Sampling and storage of natural waters for trace metal analysis." Water Research 11(9): 745-756.

Bennett S.A., Achterberg E.P., Connelly D.P., Statham P.J., Fones G.R. and German C.R. (2008). "The distribution and stabilisation of dissolved Fe in deep-sea hydrothermal plumes." Earth and Planetary Science Letters 270(3-4): 157-167.

Breier J.A., Rauch C.G., McCartney K., Toner B.M., Fakra S.C., White S.N. and German C.R. (2009). "A suspended-particle rosette multi-sampler for discrete biogeochemical sampling in low-particle-density waters." Deep Sea Research I 56(9): 1579-1589.

Breier J.A., Toner B.M., Fakra S.C., Marcus M.A., White S.N., Thurnherr A.M. and German C.R. (2012). "Sulfur, sulfides, oxides and organic matter aggregated in submarine hydrothermal plumes at $9^{\circ} 50^{\prime} \mathrm{N}$ East Pacific Rise." Geochimica et Cosmochimica Acta 88(0): 216-236.

Breier J.A., Sheik C.S., Gomez-Ibanez D., Sayre-McCord R.T., Sanger R., Rauch C., Coleman M., Bennett S.A., Cron B.R., Li M., German C.R., Toner B.M. and Dick G.J. (2014). "A large volume particulate and water multi-sampler with in situ preservation for microbial and biogeochemical studies." Deep Sea Research I 94(0): 195-206.

Charlou J.L., Donval J.P., Douville E., Jean-Baptiste P., Radford-Knoery J., Fouquet Y., Dapoigny A. and Stievenard M. (2000). "Compared geochemical signatures and the evolution of Menez Gwen $\left(37^{\circ} 50^{\prime} \mathrm{N}\right)$ and Lucky Strike $\left(37^{\circ} 17^{\prime} \mathrm{N}\right)$ hydrothermal fluids, south of the Azores Triple Junction on the Mid-Atlantic Ridge." Chemical Geology 171(1-2): 49-75.

Chin C.S., Coale K.H., Elrod V.A., Johnson K.S., Massoth G.J. and Baker E.T. (1994). "In situ observations of dissolved iron and manganese in hydrothermal vent plumes, Juan de Fuca Ridge." Journal of Geophysical Research 99(B3): 4969-4984.

Colaço A., Blandin J., Cannat M., Carval T., Chavagnac V., Connelly D., Fabian M., Ghiron S., Goslin J., Miranda J.M., Reverdin G., Sarrazin J., Waldmann C. and Sarradin P.M. (2011). "MoMAR-D: a technological challenge to monitor the dynamics of the Lucky Strike vent ecosystem." ICES Journal of Marine Science 68(2): 416-424. 
Cowen J.P., Massoth G.J. and Feely R.A. (1990). "Scavenging rates of dissolved manganese in a hydrothermal vent plume." Deep Sea Research A 37(10): 1619-1637.

Feely R.A., Gendron J.F., Baker E.T. and Lebon G.T. (1994). "Hydrothermal plumes along the East Pacific Rise, $8^{\circ} 40^{\prime}$ to $11^{\circ} 50^{\prime} \mathrm{N}$ : Particle distribution and composition." Earth and Planetary Science Letters 128(1-2): 19-36.

Field M.P. and Sherrell R.M. (2000). "Dissolved and particulate Fe in a hydrothermal plume at $9^{\circ} 45^{\prime} \mathrm{N}$, East Pacific Rise: Slow Fe (II) oxidation kinetics in Pacific plumes." Geochimica et Cosmochimica Acta 64(4): 619-628.

Fouquet Y., Ondreas H., Charlou J.L., Donval J.P., Radford-Knoery J., Costa I., Lourenco N. and Tivey M.K. (1995). "Atlantic lava lakes and hot vents." Nature 377(6546): 201201.

German C.R., Campbell A.C. and Edmond J.M. (1991). "Hydrothermal scavenging at the Mid-Atlantic Ridge: Modification of trace element dissolved fluxes." Earth and Planetary Science Letters 107(1): 101-114.

German C.R., Colley S., Palmer M.R., Khripounoff A. and Klinkhammer G.P. (2002). "Hydrothermal plume-particle fluxes at $13^{\circ} \mathrm{N}$ on the East Pacific Rise." Deep Sea Research I 49(11): 1921-1940.

Gimpel J., Zhang H., Davison W. and Edwards A.C. (2003). "In Situ Trace Metal Speciation in Lake Surface Waters Using DGT, Dialysis, and Filtration." Environmental Science \& Technology 37(1): 138-146.

Hawkes J.A., Gledhill M., Connelly D.P. and Achterberg E.P. (2013). "Characterisation of iron binding ligands in seawater by reverse titration." Analytica Chimica Acta 766: 5360 .

Huber J.A., Butterfield D.A. and Baross J.A. (2003). "Bacterial diversity in a subseafloor habitat following a deep-sea volcanic eruption." FEMS Microbiology Ecology 43(3): 393-409.

James R.H. and Elderfield H. (1996). "Dissolved and particulate trace metals in hydrothermal plumes at the Mid-Atlantic Ridge." Geophysical Research Letters 23(23): 3499-3502.

Johnson K.S., Beehler C.L., Sakamoto-Arnold C.M. and Childress J.J. (1986). "In situ Measurements of Chemical Distributions in a Deep-Sea Hydrothermal Vent Field." Science 231(4742): 1139-1141. 
Kádár E., Costa V., Martins I., Santos R.S. and Powell J.J. (2005). "Enrichment in trace metals ( $\mathrm{Al}, \mathrm{Mn}, \mathrm{Co}, \mathrm{Cu}, \mathrm{Mo}, \mathrm{Cd}, \mathrm{Fe}, \mathrm{Zn}, \mathrm{Pb}$ and $\mathrm{Hg}$ ) of macro-invertebrate habitats at hydrothermal vents along the Mid-Atlantic Ridge." Hydrobiologia 548(1): 191-205.

Kadko D., Feely R. and Massoth G. (1994). "Scavenging of ${ }^{234} \mathrm{Th}$ and phosphorus removal from the hydrothermal effluent plume over the North Cleft segment of the Juan de Fuca Ridge." Journal of Geophysical Research 99(B3): 5017-5024.

Le Bris N., Sarradin P.-M. and Caprais J.-C. (2003). "Contrasted sulphide chemistries in the environment of $13^{\circ} \mathrm{N}$ EPR vent fauna." Deep Sea Research I 50(6): 737-747.

Luther G.W., Rozan T.F., Taillefert M., Nuzzio D.B., Di Meo C., Shank T.M., Lutz R.A. and Cary S.C. (2001). "Chemical speciation drives hydrothermal vent ecology." Nature 410(6830): 813-816.

Mandernack K.W. and Tebo B.M. (1993). "Manganese scavenging and oxidation at hydrothermal vents and in vent plumes." Geochimica et Cosmochimica Acta 57(16): 3907-3923.

Mottl M.J. and McConachy T.F. (1990). "Chemical processes in buoyant hydrothermal plumes on the East Pacific Rise near $21^{\circ} \mathrm{N} . "$ Geochimica et Cosmochimica Acta 54(7): 1911-1927.

Planquette H. and Sherrell R.M. (2012). "Sampling for particulate trace element determination using water sampling bottles: methodology and comparison to in situ pumps." Limnology and Oceanography 10(5): 367-388.

Preston C.M., Harris A., Ryan J.P., Roman B., Marin R., III, Jensen S., Everlove C., Birch J., Dzenitis J.M., Pargett D., Adachi M., Turk K., Zehr J.P. and Scholin C.A. (2011). "Underwater Application of Quantitative PCR on an Ocean Mooring." PLoS ONE 6(8): e22522.

Riso R.D., Le Corre P. and Chaumery C.J. (1997). "Rapid and simultaneous analysis of trace metals $(\mathrm{Cu}, \mathrm{Pb}$ and $\mathrm{Cd})$ in seawater by potentiometric stripping analysis." Analytica Chimica Acta 351(1-3): 83-89.

Rudnicki M.D. and Elderfield H. (1993). "A chemical model of the buoyant and neutrally buoyant plume above the TAG vent field, 26 degrees N, Mid-Atlantic Ridge." Geochimica et Cosmochimica Acta 57(13): 2939-2957.

Sander S.G., Koschinsky A., Massoth G., Stott M. and Hunter K.A. (2007). "Organic complexation of copper in deep-sea hydrothermal vent systems." Environmental Chemistry 4(2): 81-89. 
Sander S.G. and Koschinsky A. (2011). "Metal flux from hydrothermal vents increased by organic complexation." Nature Geoscience 4(3): 145-150.

Sarradin P.-M., Sarrazin J., Allais A.G., Almeida D., Brandou V., Boetius A., Buffier E., Coiras E., Colaco A., Cormack A., Dentrecolas S., Desbruyeres D., Dorval P., du Buf H., Dupont J., Godfroy A., Gouillou M., Gronemann J., Hamel G., Hamon M., Hoge U., Lane D., Le Gall C., Leroux D., Legrand J., Leon P., Leveque J.P., Masson M., Olu K., Pascoal A., Sauter E., Sanfilippo L., Savino E., Sebastiao L., Santos R.S., Shillito B., Simeoni P., Schultz A., Sudreau J.P., Taylor P., Vuillemin R., Waldmann C., Wenzhöfer F. and Zal F. (2007). EXtreme ecosystem studies in the deep OCEan: Technological developments. New York, Ieee.

Sarradin P.-M., Lannuzel D., Waeles M., Crassous P., Le Bris N., Caprais J.C., Fouquet Y., Fabri M.C. and Riso R. (2008). "Dissolved and particulate metals (Fe, $\mathrm{Zn}, \mathrm{Cu}, \mathrm{Cd}, \mathrm{Pb}$ ) in two habitats from an active hydrothermal field on the EPR at $13^{\circ} \mathrm{N} . "$ Science of the total Environment 392(1): 119-129.

Sarradin P.-M., Waeles M., Bernagout S., Le Gall C., Sarrazin J. and Riso R. (2009). "Speciation of dissolved copper within an active hydrothermal edifice on the Lucky Strike vent field (MAR, 37 N)." Science of the total environment 407(2): 869-878.

Shank T.M., Fornari D.J., Von Damm K.L., Lilley M.D., Haymon R.M. and Lutz R.A. (1998). "Temporal and spatial patterns of biological community development at nascent deep-sea hydrothermal vents ( $9^{\circ} 50^{\prime} \mathrm{N}$, East Pacific Rise)." Deep Sea Research II 45(1-3): 465-515.

Taylor C.D., Doherty K.W., Molyneaux S.J., Morrison III A.T., Billings J.D., Engstrom I.B., Pfitsch D.W. and Honjo S. (2006). "Autonomous Microbial Sampler (AMS), a device for the uncontaminated collection of multiple microbial samples from submarine hydrothermal vents and other aquatic environments." Deep Sea Research I 53(5): 894916.

Toner B.M., Fakra S.C., Manganini S.J., Santelli C.M., Marcus M.A., Moffett J.W., Rouxel O., German C.R. and Edwards K.J. (2009). "Preservation of iron(II) by carbon-rich matrices in a hydrothermal plume." Nature Geoscience 2(3): 197-201.

Toner B.M., Marcus M.A., Edwards K.J., Rouxel O. and German C.R. (2012). "Measuring the form of iron in hydrothermal plume particles." Oceanography 25(1): 209-212.

Trocine R.P. and Trefry J.H. (1988). "Distribution and chemistry of suspended particles from an active hydrothermal vent site on the Mid-Atlantic Ridge at $26^{\circ} \mathrm{N}$." Earth and Planetary Science Letters 88(1-2): 1-15. 
Truitt R.E. and Weber J.H. (1979). "Trace metal ion filtration at pH 5 and 7." Analytical Chemistry 51(12): 2057-2059.

Ussler W., Preston C., Tavormina P., Pargett D., Jensen S., Roman B., Marin R., Shah S.R., Girguis P.R., Birch J.M., Orphan V. and Scholin C. (2013). "Autonomous application of quantitative PCR in the deep sea: in situ surveys of aerobic methanotrophs using the Deep-sea Environmental Sample Processor." Environmental Science \& Technology 47(16): 9339-9346.

Von Damm K.L., Edmond J.M., Grant B., Measures C.I., Walden B. and Weiss R.F. (1985). "Chemistry of submarine hydrothermal solutions at $21^{\circ} \mathrm{N}$, East Pacific Rise." Geochimica et Cosmochimica Acta 49(11): 2197-2220.

Vuillemin R., Le Roux D., Dorval P., Bucas K., Sudreau J.P., Hamon M., Le Gall C. and Sarradin P.-M. (2009). "CHEMINI: A new in situ CHEmical MINIaturized analyzer." Deep Sea Research I 56(8): 1391-1399.

Yafa C. and Farmer J.G. (2006). "A comparative study of acid-extractable and total digestion methods for the determination of inorganic elements in peat material by inductively coupled plasma-optical emission spectrometry." Analytica Chimica Acta 557(1-2): 296-303.

Yeats P.A., Dalziel J.A. and Moran S.B. (1992). "A comparison of dissolved and particulate $\mathrm{Mn}$ and $\mathrm{Al}$ distributions in the Western North Atlantic." Oceanologica Acta 15(6): 609-619.

Yücel M., Gartman A., Chan C.S. and Luther G.W. (2011). "Hydrothermal vents as a kinetically stable source of iron-sulphide-bearing nanoparticles to the ocean." Nature Geoscience 4(6): 367-371. 